\title{
The United States, Britain and the Marshall Plan: oil and finance in the early postwar era *
}

\author{
Nicholas Miller Trebat**
}

\begin{abstract}
This paper discusses United States foreign economic policy in the early post-World War II period, focusing on Anglo-American relations and the international oil industry. Contrary to popular opinion, these relations were not friendly, as one of the goals of US policymakers was to force the former power to relinquish key areas of strategic and commercial influence, such as the trading networks of the British Commonwealth and, more importantly, the oil regions of the Middle East. In particular, the paper analyzes US oil policy during the Marshall Plan. Though not questioning the Plan's overall positive impact on European economic growth, the paper argues that, with regard to the oil industry, its primary objective was not to stimulate recovery but to secure a dominant role for US producers in the Middle East.
\end{abstract}

Palavras-chave: Petróleo; Dólar; Libra; Plano Marshall; Oriente Médio.

\section{Resumo}

\section{Os EUA, Inglaterra e o Plano Marshall: petróleo e finanças no pós-guerra}

Este artigo discute a política econômica externa dos EUA no período após a Segunda Guerra Mundial (II Guerra), focando nas relações anglo-americanas e a indústria de petróleo. Ao contrário do que normalmente se pensa, essas relações não foram amigáveis. Um dos principais objetivos dos EUA nesse período foi forçar a Inglaterra a abrir espaço para empresas norte-americanas no Commonwealth britânico e nas regiões petrolíferas do Oriente Médio. O trabalho analisa especificamente a política de petróleo dos EUA durante a implementação do Plano Marshall. Apesar de não questionar o impacto positivo do Plano em termos da recuperação econômica europeia, argumenta-se que, com relação à indústria petrolífera, o objetivo central do Plano foi garantir para produtores norte-americanos uma posição dominante no Oriente Médio.

Keywords: Oil; Dollar; Sterling; Marshall Plan, Middle East.

JEL F02, F33, F54.

\section{Introduction}

Though generally regarded as close allies, early postwar relations between the United States and Britain were characterized as much by conflict and rivalry as they were by notions of shared values and a faith in democracy or liberal capitalism. Weakened by external debt and no longer in possession of the world's dominant international currency, Britain after World War II saw itself in many ways at the

* Article received on January 28, 2016 and approved on April 2, 2018.

** Associate Professor at the Instituto de Economia da Universidade Federal do Rio de Janeiro, Rio de Janeiro RJ, Brasil. E-mail: nicholasmtrebat@gmail.com. 
mercy of US planners, who used their financial and economic leverage to extract concessions from the British, particularly in key areas of strategic and commercial influence such as the trading networks of the Commonwealth and the oil regions of the Middle East.

This paper focuses on US oil policy during the Marshall Plan, also known as the European Recovery Program (ERP), which lasted from 1948 and 1952. As discussed below in more detail, this policy was designed not to stimulate European industrial recovery, but to secure a dominant role for US oil producers in the Middle East. Fears of Soviet expansionism aside, controlling access to the world's energy reserves was perhaps America's primary geopolitical objective in the early postwar era, as it would assure US influence over the economic and military policies of Western Europe and Japan.

Section 2 discusses the financial aspects of Anglo-American relations during and after the war, specifically Britain's financial dependence on the US Treasury. US officials and members of Congress took advantage of this state of dependence in order to obtain trade concessions from Britain as well as to ensure it would play a subordinate role in a world financial system based on the dollar. Section 3 explains how British financial dependence led to the "Anglo-American Oil Agreement", a memorandum of understanding signed between the US and Britain in 1944. The Agreement guaranteed an "open door" for US oil investment in the Middle East, still under British influence at the time and already considered the world's most valuable source of energy reserves. Our discussion of the Agreement and the importance to the US of an open door in this region, a major policy goal since the 1920's, allows us to understand the role of oil in the Marshall Plan, the subject of Section 4. In the opinion of American officials at the time, US hegemony in the postwar period would largely depend on US control over world energy supplies. Securing access to Middle East oil reserves was thus seen as essential, and this, we will see, is why American officials were willing to go to great lengths to ensure that these reserves fell into US hands. Section 5 discusses US opposition in the late 1940's to the construction of European-owned oil refineries in Europe. Section 6 concludes the paper.

\section{2 the role of the dollar and British financial dependence on the United States}

As is well known, the United States emerged from World War II as the world's foremost economic and military power, a role Great Britain had previously occupied for over a century. In 1945, the United States held roughly $75 \%$ of the world's gold reserves and was responsible for $50 \%$ of world industrial production. It was the world's largest exporter, importer and creditor nation, with a current account surplus of $\$ 11.5$ billion, more than ten times the surpluses it had registered in the late 1930's. Europe, including Britain, had of course been severely weakened by the war. British exports in 1945 were at one-third their 1939 level, and its stock of foreign 
direct investment fell in this period by some 4 billion pounds (Gardner, p. 178). The reduction in income earned abroad, a major component of the British balance of payments, led to a substantial decline in the Bank of England's dollar and gold reserves. As the American diplomat Richard Gardner noted in Sterling-Dollar Diplomacy (1956), "Among the most far-reaching consequences of the $2^{\text {nd }}$ World War were the changes it brought to the economic positions of Britain and the US. The contrast was almost complete."

The years immediately following World War II (WWII) were marked by a dollar shortage caused by US balance of payment surpluses and European indebtedness to US banks and the Treasury. The "dollar gap" was a major obstacle to the creation of a US-led world capitalist system. The dollar's role as the primary international currency, formally established at the Bretton Woods negotiations in 1943, imposed on all countries outside the Soviet bloc the need to earn enough dollars through the sale of goods and services to the rest of the world to pay for imports and avoid balance of payment problems.

The Marshall Plan was a response to this challenge: its purpose was to provide Europe with the foreign exchange needed to recover while at the same time maintaining demand for American exports. In addition to helping convince Western Europe that greater economic integration with the Soviet Union was unnecessary, American dollars would buy time for countries of the region to reestablish industry and recreate competitive export sectors. Once Europe's capacity to earn dollars was restored, the region's integration into an American-led world economic order would be complete.

During World War II, Britain and the other Allied Powers had turned to American banks and the US Treasury for funding and supplies. In 1941 President Roosevelt signed the Lend-Lease Act, approving US\$1 billion in aid to Britain. By the time the war was over, Britain had taken some US\$ 30 billion in Lend-Lease aid from the US (Gardner, 1956, p. 172). Lend-Lease was not "aid" strictly speaking in that it was part of the US contribution to the war effort and also in that it came with strict conditions attached, the most important of which was that England could not "permit any export of Lend-Lease goods, articles made with Lend-Lease goods, or even 'substantially similar' articles", as stipulated in the Eden White Paper of 1941. This clause, which hindered British exports at a time when the country desperately needed foreign exchange, was included in the loan negotiations as a result of pressure by American exporters, who were "[c]oncerned lest Lend-Lease assistance should be used by Britain in commercial competition with the United States" (Gardner, 1956, p. 173).

To maintain its influence over British trade policy, the US Congress prohibited the Bank of England from using Lend-Lease dollars to build up its dollar 
reserves. Gardner (1956) explains: "[U]ntil the very last months of the war the American Government exerted continuous pressure to keep British reserves to a figure not greatly in excess of US\$ 1 billion." By forcing the British to, as Gardner put it, "scrape the bottom of the barrel", Congress and the Treasury Department ensured the US would have maximum "bargaining power" (Gardner 1956, p. 174) to demand tariff reductions on American goods sold within the British Commonwealth, also known as the "sterling area" (composed of Britain, British territories and former colonies, all of which used the British pound as a primary means of payment).

After a severe dollar shortage in 1939, Britain created a system of "dollar pooling" in which Commonwealth countries deposited their export dollars in British banks. These dollars were then redistributed among the Commonwealth countries, with Britain allotting the largest share to itself. A rigorous system of monetary controls on the withdrawal of dollars from these accounts limited investor demands for currency conversion and forced all of the Commonwealth countries to reduce expenditures on US goods. In addition, England maintained a system of "imperial preference", establishing preferential tariffs on goods produced within the sterling area. Intended to limit the drain of reserves from the dollar pool, these measures necessarily involved discrimination against products supplied by US companies.

Britain maintained exchange controls on dollar expenditures within the Commonwealth until December 1945, when it signed the "Anglo-American Financial Agreement", consisting of a much-needed \$3.75 billion-dollar US loan. Despite British insistence that it could not afford to lift these controls, US officials would approve the loan only on the condition that they abolish imperial preference and the dollar pool. Britain accepted these terms, and the US gave it one year to comply, after which it would have to make the sterling freely convertible.

Dollar convertibility quickly turned into a disaster. As stipulated in the accord, England restored current account convertibility for dollar transactions in July 1947. One month later, the British Treasury was forced to suspend convertibility, as it was overwhelmed by demands for currency conversion from US and other investors holding large sterling balances.

With the pound and the British economy in such a fragile state after the war, one wonders why the US would insist so aggressively on the lifting of exchange controls. One reason, discussed above, was the US's desire to open the sterling area to US exporters and investment. Another reason lies in the US's plans for the pound's role in the post-war international financial order. While insisting at the Bretton Woods negotiations on a preeminent role for the dollar (accomplished by way of rejection of British proposals for an International Clearing Union and other such mechanisms that would have forced surplus countries such as the US to make foreign 
exchange available to deficit countries), Treasury officials believed that European economic recovery depended on the restoration of London as a regional financial center. US grants and loans would enable the Europeans to keep importing products from outside of Europe, while the pound and British banks would be used to finance intra-European trade. This, some US planners hoped, would permit more open financial and commercial policies in Europe, benefitting the US as the world's largest exporter of goods and capital (Block, 1977, p. 57-58).

That Britain received the bulk of US aid and loans during the period under analysis supports the argument that US strategy was to transform Britain and the pound sterling into "junior partners" in a world economic and monetary order dominated by US companies and the dollar.

\section{The oil agreement}

Signed in 1944, the "Anglo-American Oil Agreement" was never given the status of a formal treaty by the US Congress, which relegated the agreement to a "memorandum of understanding". Nonetheless, like the Financial Agreement, the accord is an important symbol of US postwar hegemony, as it opened up the world's most valuable oil regions to US investors.

Britain retained important colonies and spheres of influence in the 1940's, such as in the Middle East, already recognized for its oil potential. Prior to the Oil Agreement, the main obstacle to US investment in this region was the already wellestablished British presence. British companies enjoyed exclusive rights over oil exploration in several of the Middle East's most promising regions, notably Persia (Iran) and large parts of Mesopotamia (Iraq), Kuwait and Bahrein. Ever since the 1920 's, US officials had tried, with mixed success, to increase access for US oil companies to these areas of British influence. The Oil Agreement eliminated this obstacle, as Britain agreed to an "open door" policy on overseas oil investment, abdicating its rights of exclusivity in the Middle East.

It is difficult to exaggerate the importance of this abdication. After World War I, the Middle East was essentially divided up between France and Britain, with Britain controlling much of Persia and Mesopotamia and France assuming power over less valuable areas in Jordan and Anatolia (now part of Turkey). The US State Department looked upon this development with suspicion, complaining that the agreement violated "principles of equality" among the war allies. US officials feared the British were "using their political supremacy in the Middle East to establish economic supremacy in the world oil trade" (Multinational Oil Corporations and US Foreign Policy 1975, p. 35). Citing the long-term concession agreements Britain had signed with Kuwait and Bahrein (guaranteeing, for up to 60 years, exclusive rights 
over exploration to British companies), US oil executives in 1919 stated (Multinational Oil Corporations and US Foreign Policy 1975, p. 35):

If under a protectorate or any other form of control...British and French interests...should be permitted to gain and maintain an exclusive right of development in Persia and in Turkey, to say nothing of the other oil-bearing lands embraced within the peace settlements...the results to the American petroleum industry might eventually prove to be disastrous.

The Roosevelt Administration made aggressive efforts throughout the 1920's and 30's to open the Middle East to US investment. These efforts were partly successful. In 1927, the US government negotiated the entrance of US majors into the Anglo-French consortium exploiting the enormous Kirkuk oil field of Iraq. As oil executive and State Department consultant Charles Rayner noted in Congressional testimony in 1945, "American participation in [Iraq] would have never been secured without the strong, consistent, and frequently insistent pressure brought to bear" on British and French authorities "by the [State] Department" (American Petroleum Interests in Foreign Countries, p. 23).

Despite such early success, official documents from the 1930s and 1940s attest to US concern with British "imperialism" and "dominance" in the Middle East. In the 1940's, the US government continued to encourage US companies to acquire oil concessions in the region, and even pondered the creation of a state-owned oil concern, to be named the Petroleum Reserves Corporation, to purchase oil concessions outside the US, above all in Saudi Arabia (Painter, 1986, p. 38-42).

Why such concern for British imperialism in the Middle East, especially given the large oil reserves still available in the US? The concern stemmed in part from fears that domestic crude oil supplies would be insufficient to meet military and civilian needs (Painter 1986, p. 39). More importantly, by the end of World War II, and in fact well before, it had become clear that global economic and military power required control over oil supplies (Klare, 2001). As observed in Foreign Affairs soon after the war: "In the contemporary world oil is power. It is power in time of peace to develop great industrial establishments", and power in time of war "to expand industry and to exert strength at great distances" (Hoskins, 1951, p. 229).

The world wars had convinced US officials that the vast oil reserves of the Middle East were a "stupendous source of strategic power" and "one of the greatest material prizes in world history" (Richman 1985). The "answers" to Western anxieties concerning future oil supplies, Hoskins (1951) noted, "point to the Middle East", making it essential to any "United States plan of strategy for world security...that the oil fields of the Middle East do not fall into totalitarian hands" (Haskins 1951, p. 230 and p. 236). Regarding Saudi Arabia, Navy Secretary James Forrestal expressed his opinion at the time that American corporations should detain 
complete control over the country's oil reserves: "I don't care which company or companies develop the Saudi reserves, but I think most emphatically that it should be American" (Quandt, 1981, p. 48; author's emphasis).

In addition to its profit potential, due to low production costs, the Middle East was the natural supply source to Western Europe and Japan. Control over the region, thus, would give the US influence over the economic and military policies of almost all the major participants in World War II. Discussing US policy with regard to postwar Japan, top State Department official George Kennan remarked: "If we in the Western world could work out controls...adept enough...to have power over what Japan imports in the way of oil and such other things as she has got to get from overseas, we would have veto power on what she does in the military and industrial field" (Schwarz 1996). The Middle East thus became "the indispensable key to the defense of the American global position" in the postwar era, with its "intrinsic importance" deriving from Japan and Western Europe's near total dependence on its energy reserves, without which "economic life would come to a sudden halt" (Tucker, 1980, p. 248).

The Oil Agreement notwithstanding, US officials in the early postwar years believed American control over Middle East oil was far from a sure thing. Oil, thus, remained a sensitive issue in 1948 when the US government approved the Marshall Plan for Europe.

\section{The Marshall Plan and the sterling-dollar oil conflict}

The Marshall Plan is the colloquial term for the European Recovery Program (ERP), created during the Truman Administration to grant and administer funds to 17 European countries between 1948 and 1952. England, France, Germany and Italy, received the bulk of the Marshall Plan funds (almost 70\%), with the rest distributed among Norway, Austria, Greece and others.

Despite expectations that the European economies might recover in the absence of major government intervention, by 1947 it appeared that the situation was getting worse. The persistence of recession across the region, as well as massive capital flight from Britain following the Financial Agreement, convinced US leaders of the need for more drastic measures.

US policymakers devised the Marshall Plan for two main reasons. The first was that a European recovery would sustain demand for American products, regarded as crucial given the huge increase in US industrial capacity during the war. Hogan (1987) explains: "[Truman] offered the Marshall Plan as an alternative to a massive expansion of defense expenditures and the collapse of European export markets, which together would bring economic depression and sweeping new 
controls over labor, industry, and agriculture." Top State Department official William Clayton noted in 1945 (Block, 1977, p. 40):

We simply can't afford after this war to let our trade drop off...we will probably have to sell $\$ 10$ billion worth of goods a year abroad if we want to have relatively high level employment... In other words, we have got to export three times as much as we exported just before the war if we want to keep our industry running at somewhere near capacity.

A European recovery was also seen as necessary to avert social change with some kind of anti-capitalist component, not only in Europe but perhaps even in the US itself, as the future Secretary of State Dean Acheson suggested before Congress in 1944: "We cannot go through another ten years like the ten years at the end of the Twenties and the beginning of the Thirties, without having the most far-reaching consequences upon our economic and social system." Acheson added: "The important thing is markets. We have got to see that what the country produces is used and is sold under financial arrangements which makes its production possible... You must look to foreign markets" (Block, 1977, p. 40).

US exports had increased from US $\$ 3$ billion to $\$ 15$ billion since the late 1930s, and almost $30 \%$ of US exports at the beginning of the war had gone to the sterling area. Thus, with Japan and most of Western Europe debilitated, US planners saw this area as key to maintaining merchandise and "invisible" exports such as profit remittances and interest earned on loans and securities. It was thus essential that Britain, under attack by speculators and totally dependent on US dollar loans, not take the logical course of restricting imports within the sterling area and imposing controls on the conversion of sterling into dollars.

From the outset, Congress strove to ensure the Economic Cooperation Administration (ECA), the agency created to administer the ERP, would attend to US business interests. Legislators and corporate executives participating in postwar planning insisted the ECA should be run not by "diplomats" or "civil servants" but by businessmen intent on promoting US industry. To avoid the influence of "civil servants", Congress established the ECA as an independent agency, meaning it did not take orders from the State Department. As Senator Arthur Vandenburg described, the ERP was conceived as a "bipartisan public-private partnership in which essentially private leaders would make operational decisions and collaborate with their public counterparts in the formulation of policy. The administrator...would be recruited from the private sector and run his agency like a 'business enterprise"" (Hogan 1987, p. 107). The first director of the ECA, Paul Hoffman, was chief executive of the Studebaker Corporation, then one of the largest automobile manufacturers in the US. 
Petroleum and petroleum products (crude oil and oil products such as gasoline and diesel fuel) accounted for a large part of funds disbursed through the Marshall Plan. In addition to the dollar's role as an international means of payment, American companies were major players in the international oil industry, dominating oil production (US companies supplied roughly half of Europe's crude oil consumption), shipping, refining and distribution. After 1945, US companies also dominated the oil supply and services industry, responsible for engineering services and for manufacturing the equipment needed for oil exploration, drilling and extraction. Operating through European subsidiaries, the American companies needed to convert a large part of their revenues denominated in European currency into dollars in order to remit profits, amortize debt and pay salaries to American employees. Painter (1984, p. 361) sums Europe's predicament up well: "In short, if Europe were to meet its energy needs with imported oil, it would need dollars to pay the bill."

Like their American counterparts, the European oil companies were themselves a source of dollar drain for the Marshall Plan countries, especially the large multinationals Royal Dutch Shell and the Anglo-Iranian Oil Company (AIOC, later known as British Petroleum), the latter controlled by the British government. Shell and AIOC needed dollars not only to import oil and capital goods from the United States, but to pay taxes and royalties to foreign governments in the oilproducing regions.

The European multinationals, however, demanded on average much fewer dollars for their day-to-day operations than the American majors, creating a significant difference for the Marshall Plan countries between "dollar oil", that is, oil and oil products supplied by the American companies, and "sterling oil", supplied by Shell and AIOC.

Citing scarce dollar supplies, the British Treasury in 1949 introduced measures that set off what became known as the "sterling-dollar oil conflict". First, it reduced import licenses for oil purchased from American oil companies within the sterling area. Then it barred US companies from selling products in exchange for sterling in countries outside the sterling area. To enforce this measure, the British Treasury made it illegal for British banks to transfer sterling from accounts based outside the Commonwealth to the British accounts of American oil companies. Finally, in December, the British Ministry of Fuel and Energy declared that as of January 1950, Commonwealth countries would reduce their consumption of dollar oil from 13 million metric tons to 9 million metric tons.

Indeed, in 1949 Shell and AIOC held an estimated 4 million metric tons of excess oil reserves and refining capacity, precisely the amount by which consumption of US-supplied oil was to be reduced. The basic idea, thus, was to take 
advantage of Shell and AIOC's excess capacity and replace unnecessary expenditures on dollar oil with sterling oil.

The US oil companies, backed by the State Department, lobbied heavily to eliminate these restrictions, contending that the measures amounted to "discrimination". The British Treasury countered by pointing out that American companies demanded a much greater quantity of dollars for their operations than the Europeans, a claim supported by Horst Mendershausen, an employee of the Federal Reserve Bank of New York at the time and author of "Dollar Shortage-Oil Surplus" (1950). Mendershausen's calculations substantiate the claim that American companies were a much larger source of dollar drain than the Europeans. According to Mendershausen (1950, p. 15), a barrel of oil sold by US companies in the "sterling block" (the set of countries trading primarily in British currency) resulted in a demand for conversion roughly four times greater than a barrel sold by the Europeans:

[I]t is true that 'sterling company' oil costs Britain dollars and so does 'dollar company' oil. But the latter seems to cost on the average nearly four times as much per barrel...assuming that $\$ 260$ million of sterling company oil could be sold for dollars in 1950 as expected, the net dollar outlay of all sterling-company oil would be as low as one-fifth of the gross cost of dollar oil, per unit. This seems to be the essence of Britain's case against dollar-company oil on balance of payments grounds.

Mendershausen (1950, p. 6) emphasizes that the British exchange policy was not intended simply to promote British companies or British interests at the expense of the Americans:

$[\mathrm{R}]$ ather than a commercial conflict cloaked in national balance of payments arguments, this is an international balance of payments conflict that is turning the agents of international commerce from shared expansion toward a fight over restricted markets. To follow a policy of dollar saving naturally means to encourage the foreign competitors of American business.

For Mendershausen, the dollar oil conflict stemmed from two basic problems. One was the scarcity of dollars in Britain, which forced the British Treasury to find ways to save on its dollar bill. The second was the excess supply of oil in the international market, due to the fall in demand after World War II and successful oil exploration in the Middle East and Dutch East Indies. This made an orderly distribution of world oil markets impossible for the multinational oil giants, forcing them into competition with each other to find buyers for their oil reserves.

Mendershausen (1950) points out further that England's dollar-saving measures should have come as no surprise to the Americans, given the physical destruction caused by the war and the loss of competitiveness of British exports, and 
adds that were it not for US financing and loans, England would have been forced to impose restrictions on dollar oil well before 1949.

The British restrictions on US oil companies had an immediate impact. According to State Department calculations in May 1950, dollar oil was being substituted by sterling oil at a rate of 135,000 barrels per day (b/d), equivalent to $9 \%$ of US production abroad. Furthermore, due to the reduction in sales, the ArabianAmerican Oil Company (Aramco), a joint-venture between Standard Oil of California, Texaco, Standard Oil of New Jersey and Socony-Vacuum, had reduced oil production in Saudi Arabia. Given the weakness of the Saudi regime, US officials and oil executives feared a reduction in Aramco's production would upset the Saudis and lead to invitations for European companies to invest in the kingdom (see Section 5).

To persuade the British to reverse their policies, the US companies promised to convert no more than $50 \%$ of their sterling revenues into dollars, as well as purchase more goods and services produced within the Commonwealth. The British government refused, arguing that the mere accumulation of sterling balances by the American companies creates "continuous pressure for conversion, direct or indirect, and the existence of additional balances of this kind, even when effectively blocked, impairs the strength of the sterling." (Mendershausen, 1950, p. 10).

According to the British Treasury, the only way in which American sales could surpass the 9 million metric ton ceiling in the sterling area would be if the companies increased their purchases of goods and services in the sterling area with dollars. That is, the companies would not only have to agree to purchase more sterling-area products; they would have to exchange dollars in order to do so. This proposal makes very clear that Britain's objective was to preserve its dollar supply. As for the American companies' desire to sell outside the sterling area (but within the sterling block), the British government again stood firm, arguing: "[The difficulties experienced by the Americans] are merely one aspect of the dollar shortage which, as long as it persists, cannot fail adversely to affect US exports generally. The United Kingdom is not responsible for this shortage and cannot afford any dollar burden in order to assist the US oil companies" (Mendershausen, 1950, p. 10)

Having failed to convince the British, the US oil companies turned to the American government for support. Indeed, as mentioned above, these companies already had strong public support, not simply because of the many US politicians with ties to the oil industry but, more importantly, because of the recognition among government officials that the US oil concessions abroad, above all in the Middle East, were of major economic and geopolitical importance. Maintaining these 
concessions meant securing stable sources of demand for the oil produced within them, hence the importance of defending US access to European consumers.

Mendershausen notes that the companies actively sought the support of the US Congress: "Since the entry of these companies into the foreign field in the past and their expansion there during and after the war (World War II) were prompted and supported by the US government, they now appeal to Congress, the State Department, and ECA, for support and for measures that would make it costly for Britain to follow its announced course."

Testifying before Congress in 1945, the oil executive and State Department consultant Charles Rayner explained (American Petroleum Interests in Foreign Countries 1945, p. 1):

The Department of State has...taken the position that the public interest of the United States requires maximum conservation of domestic and nearby reserves and large-scale expansion of holdings in foreign oil reserves by United States nationals. It has, therefore, actively supported the efforts of United States petroleum interests to secure and to consolidate concessions abroad.

On Capitol Hill, animosity towards the British "currency discrimination" was intense. Senator Tom Connaly of Texas vilified the British government for its "hostile" policies. In 1950, Connaly, along with other Congressmen, suggested that the US withhold Marshall Plan funds for Britain until the country eliminated its exchange restrictions. Connaly declared: "[T]he proposed policy of the British government to require its Dominions to substitute 'sterlingized' oil for dollar oil... is a British act of hostility directed at our economy, when the US is making stupendous gifts to Britain" (Mendershausen, 1950, p. 21).

Congress's anger reflects another element of the dollar oil conflict, which was the need to protect domestic oil producers (known as "independents") from lowcost oil imports. Due to the reduced demand in Europe in the late 1940's, multinationals such as Standard Oil of Jersey (now Exxon), Socal (Chevron) and Gulf cut the price of oil imported from production fields in the Middle East in order to increase sales in the US. The result was a dramatic increase in US consumption of Mideast oil. While domestic production increased 8\% between 1947 and 1950, Middle East production rose 109\%. In fact, in 1949 oil production in the US fell as the Texas Railroad Commission (the state's regulatory body for oil production) ordered production cuts to keep oil prices high.

Table 1 shows the rapid increase in US imports between 1945 and 1949. $75 \%$ of these imports came from six multinationals, all active in the Middle East. 
Table 1

US oil production and oil imports (million metric tons)

\begin{tabular}{|c|c|c|c|}
\hline & US Production & Imports & Imports/US Production (\%) \\
\hline $\mathbf{1 9 4 5}$ & 250.5 & 15.6 & 6.2 \\
\hline $\mathbf{1 9 4 6}$ & 253.7 & 18.7 & 7.4 \\
\hline $\mathbf{1 9 4 7}$ & 272.6 & 21.8 & 8 \\
\hline $\mathbf{1 9 4 8}$ & 296.2 & 25.7 & 8.7 \\
\hline $\mathbf{1 9 4 9}$ & 273 & 32.5 & 11.9 \\
\hline
\end{tabular}

Source: Mendershausen (1950).

The rise in imports provoked a reaction not only from domestic producers but from the military officials, concerned that low-cost imported oil would reduce oil investments in the US. Lower domestic production, army officers argued, would put the US at a disadvantage in the event of another major war.

Had there been no pressure within the US to limit oil imports, the British measures to save on its dollar bill would probably not have caused much alarm: American oil companies could have shipped imported oil to the US, soothing fears that US oil producers would not be able to consolidate their positions in the Middle East. The independents and the Armed Forces, however, were powerful constituencies able to block further increases of imports into the US. That left the European market as the only alternative.

As explained above, however, the US could not simply force Europe to buy large amounts of dollar oil. The whole region faced a severe shortage of foreign exchange, requiring dollar-saving measures identical to those adopted by Britain. The Marshall Plan thus emerged as a solution to America's oil problem, for if the Europeans could not afford to buy dollar oil, then the US government would supply them with the dollars necessary to do so.

And this is precisely what the US government did. Oil was the largest single item in the dollar budget of the Marshall Plan countries (Effects 1949, p. 523). Roughly $10 \%$ of Marshall Plan funds were allocated to oil and oil products alone, more than $70 \%$ of which was supplied by only three US companies: Standard Oil of New Jersey (48.8\%), Caltex (14\%) and Socony-Vacuum (9.2\%). In keeping with Section 112 of the ECA Act of 1948, which stipulated that "the procurement of petroleum and petroleum products...shall to the maximum extent practicable be made from petroleum resources outside the US", 70\% of the oil supplied through the Marshall Plan came from Latin America and the Middle East (roughly $35 \%$ apiece) ${ }^{1}$. Given that the first major discoveries in the Middle East took place only in the late

(1) Report on the Third World Petroleum Congress (1951, p. 49). 
1920 and 1930's (Kirkuk - Iraq - in 1927, Agha Jari - Iran - in 1938), it is a testament to both the productivity of the oil fields and the desire of US companies to find markets for this oil that such a substantial portion of Marshall Plan oil came from this region. The extensive use of ECA funds to bolster the sales of US multinational oil production even elicited a remark from ECA director Paul Hoffman, who noted that the Marshall Plan countries had remained 'good customers of the [U. S.] petroleum industry' because of dollars furnished by ECA" (Painter, 1984 , p. 362-363).

\section{US opposition to refinery expansion in Europe}

ECA officials recognized that selling US oil products in European markets required more than a subsidy program. To ensure demand for the American companies, the ECA also had to prevent Marshall Plan funds from being used to stimulate the growth of local refining capacity in Europe.

Refinery expansion was the key to reducing Europe's dollar expenses on oil and oil products. With its industrial park destroyed by the war, much of Western Europe was forced to import not only crude oil from American companies but more expensive oil products such as gasoline, diesel and kerosene. To eliminate this source of dollar drain, the Marshall Plan countries wanted to use the funds to build European-owned refineries. This would allow them to reduce expenditures on American-supplied crude oil and oil products. Since the large US companies were vertically-integrated, the existence of more American-owned refineries meant more imports of crude oil produced by these same companies. This resulted in a greater outflow of dollars from European central banks. An increase in European-owned refining capacity would allow the Marshall Plan countries to reduce their purchases of dollar oil, improving their balance of payments.

Painter (1984, p. 372) explains that the "world shortage of dollars created considerable pressure" for refinery expansion in Europe:

As long as there was a shortage of refinery capacity in the Eastern Hemisphere... Western Europe would be forced to rely to a certain extent on dollar refined products if not crude oil. Thus, the refinery expansion program of the Marshall plan countries was also of key importance to the future positions of sterling and dollar oil.

Soon after the conception of the Marshall Plan, the Organization for European Economic Cooperation (OEEC) was created to propose investment projects to the ECA. In 1948, the OEEC submitted a development proposal to the ECA that included significant funds for the acquisition of refining equipment. The ECA's chief oil consultant Walter Levy, with extensive ties to the American oil industry, called the OEEC's proposal "ambitious" and informed the OEEC that the 
ECA would not discuss refinery investments until it came up with a more "reasonable" and "coordinated" proposal. Levy insisted on limiting the use of ECA funds to purchase petroleum equipment. Painter (1984, p. 373) explains: "Levy and the oil people in ECA opposed aiding the expansion of the European oil industry, arguing that this would harm U.S. oil companies operating overseas".

Several ECA officials opposed Levy, arguing that "the general interest of European recovery took precedence over the special interests of oil companies". Nonetheless, Levy, with critical support from the State Department and the US military, succeeded in restricting ECA investment in oil production and refining equipment, justifying this policy with the claim that the "the loss of markets for USowned foreign oil would jeopardize the security of the concessions held by US companies in Latin America and the Middle East". The State Department concurred, citing a "vital United States interest in American-owned foreign oil" (Painter 1984, p. 373).

In response, the influential British magazine The Economist criticized the ECA oil program in 1949 for amounting to "charity", and noted that without heavy investments in refineries and specialized equipment, the Marshall Plan would exacerbate the problem it was intended to fix, which was Europe's balance of payments deficit:

American assistance will certainly be needed for many years to come, but it will be far healthier and more effective if it takes the form of assistance in removing the deficit than of charity in meeting it. There is a sense in which Marshall aid creates the dollar deficit...so long as European purchasing power in world markets is buttressed by Marshall dollars, the chances of recovery and restoration of equilibrium become slimmer.

US officials insisted that ECA funds must not be used in a way that would harm American oil producers. As noted above, the American and European oil majors were vertically-integrated companies, producing crude oil in various parts of the world and shipping this crude to their own refineries in the US and Europe. Thus, the State Department's concern was that, with the expansion of European-owned refining capacity, oil produced in the Middle East by the European oil giants would increase rapidly, while American oil companies in the Middle East would have few outlets for their crude oil production. This, US officials and corporations feared, would reinforce ties between the Europeans and the oil kingdoms and weaken America's position in the region. Saudi Arabia, home to the largest oil fields, caused particular concern, as King Ibn Saud had since the early 1940s been unhappy with the amount of royalties he was receiving from the US-owned Arabian-American Oil Company (Aramco), which detained exclusive rights to oil exploration in the country. 
Aramco had expressed fears during World War II that the British were gaining footholds in Saudi Arabia after Britain offered Ibn Saud financial support and proposed opening a British bank in the country to shore up the leader's political and military position. Aramco "feared the plan would draw Saudi Arabia into the sterling bloc and that they might not be able to maintain the 'American character' of the company" (Painter, 1977, p. 35). These fears resurfaced with the prospect of an expansion in European refining capacity in the late 1940s. A sharp rise in Britishowned oil production in the Middle East at the expense of American production, and the resultant "displacement of dollar oil by sterling oil in world markets...would place the US companies in an untenable position, and they could lose their concessions" (Painter, 1984, p. 374).

Testifying before Congress in 1949, O.E. Bransky, head of the ECA Petroleum Branch and former Standard Oil executive, explained that "British and Anglo-Dutch" oil companies presented "special problems" for the financing of refinery expansion in Europe: "[W]e have had to consider the implications of this [refinery] program upon the broader United States national interest, including our desire for strategic reasons to maintain American-owned concessions abroad" (Petroleum Study 1950, p. 88). Though accounting for $60 \%$ of world oil demand, US oil consumption had not grown enough in 1946 and 1947 to absorb the oil production of US majors operating in the Middle East and Latin America. Furthermore, as explained above, large imports of Middle East oil into the US was out of the question. Thus, it was "essential that ECA do its best to prevent a degree of overexpansion that, because of the dollar shortage, would seriously reduce the market outlets for American-owned oil and thus jeopardize American-owned concessions in foreign lands" (Effects of Oil Imports on Domestic Producers, 1949, p. 523).

The OEEC returned in 1949 with a much less ambitious refinery program. The organization proposed an expansion of refinery capacity sufficient to allow European companies to supply Western Europe, leaving the world market outside of this region to the US companies. Recognizing that, once the refineries were built, European governments would have every incentive to save dollars by imposing tariffs or quotas on dollar oil, the ECA accepted the proposal only tentatively, stating that it was opposed to any kind of "currency discrimination" or any kind of "undesirable commercial restrictions" used to promote sales of non-American oil companies (Effects of Oil Imports on Domestic Producers, p. 530).

Between 1948 and 1951, the ECA approved only US\$ 24 million for the expansion of refinery capacity in Europe (Mendershausen, p. 50), a very small sum relative to the US\$ 1.2 billion allocated over the course of the Marshall Plan for oil products supplied by US companies (Painter 1984, p. 375). In 1949 alone the ECA approved US\$ 485 million for European imports of dollar oil. Mendershausen (1950, 
p. 51) estimated that ECA funds would cover no more than $3 \%$ of the total cost of refinery expansion in Europe.

This meager funding reflected, in Mendershausen's words, a policy of "using the ECA as an instrument to prevent the expansion of such oil production facilities abroad as might serve as substitutes for American-company facilities in times of lagging effective foreign demand" (p. 50). This policy was largely successful, since "Without ECA, the British would probably have spent far more on [refinery] expansion, since such investment would have produced per dollar the quickest and largest dollar return" (Mendershausen 1950, p. 52).

Bransky, the head of the ECA Petroleum Branch, was also of the opinion that the ECA had dissuaded the Europeans from investing in refining capacity, thus providing an important service to the US oil industry and US strategic planning:

$[\mathrm{H}]$ ad there been no Marshall Plan, these countries would have had to give an even higher priority to the expansion of nondollar crude-oil production and refinery capacity. In other words, the less dollars they had, the more they would have spent on petroleum equipment. Very few dollars would have been spent on the purchase of oil from American companies and the dollar expenditure for oil would have been reduced very rapidly as nondollar oil became available.

\section{Concluding remarks}

America's rise to world hegemony in the early postwar era was in many ways a power-grabbing affair. The US government exploited British and, in general, European economic and financial dependence to ensure American predominance in the international oil industry. A common assumption of much scholarly analysis is that fear of Soviet expansionism drove US foreign policy after World War II. Regarding commercial interests and oil policy, however, policymakers in the 1940's were concerned not with Soviet but British domination of the sterling area and the oil resources of the Middle East. Being too weak to defend the remnants of its empire, Britain was forced to open these spheres of influence to US exporters and oil investors.

The analysis of oil policy during the Marshall Plan offers a striking example of how US policy towards Britain, and indeed all of Europe, was guided by the basic goal of securing hegemony at the expense of potential rivals. As the editors of The Economist pointed out in 1949, given the role of petroleum expenditures in weakening Europe's balance of payments, US officials jeopardized the region's industrial recovery by attempting to limit the growth of European-owned refining capacity. This is the extent to which they were willing to go to sustain the market share of American oil companies in Europe. 
It would be a mistake, however, to conclude that economic policy during the Marshall Plan reflected simply the influence of the oil lobby. Top US strategists in the early post-war period, such as Acheson, Forrestal, Kennan and others, did not seem particularly interested in promoting the interests of specific companies. They seemed more concerned, rather, with the preservation of America's "economic and social system" as a whole, dependent, in part, on US control over supplies of strategic raw materials abroad.

Thus, the State Department's recognition of the enormous "strategic power" of Middle East oil resources, discussed in Section 2, refers not only to the profits oil companies could reap from them but to the "veto power" these resources would give the US over its main industrial rivals. This seems to be one of the basic lessons of US foreign policy in the mid-to-late 1940's: US motives cannot be explained away by simplistic references to the "Soviet menace" or the influence of special interest groups. Other aims, such as the quest for world hegemony and interstate rivalry among the capitalist powers of the West themselves, must also be considered.

\section{References}

AMERICAN Petroleum Interests in Foreign Countries 1945, Special Committee Investigating Petroleum Resources, United States Senate, $79^{\text {th }}$ Congress, $1^{\text {st }}$ Session, Jun.

BLOCK, F. Origins of international economic disorder: a study of United States international monetary policy from World War II to the present. 1977.

EFFECTS of oil imports on domestic producers. v. I, II, III, Hearings before the Select Committee on Small Business, United States House of Representatives, $81^{\text {st }}$ Congress, $1^{\text {st }}$ Session, 1949.

GARDNER, R. Sterling-dollar diplomacy. Oxford University Press, 1956.

HASKINS, H. Needed: a strategy for oil. Foreign Affairs, Jan. 1951

HOGAN, M. The Marshall Plan, America, Britain and the reconstruction of Western Europe, 1947-1952. 1987.

KLARE, M. The geopolitics of war. The Nation, 2001.

MENDERSHAUSEN, H. Dollar shortage and oil surplus. Harry S. Truman Library, Record Group 286, Records of Gordon Gray, Special Assistant to the President. 1950.

MULTINATIONAL Oil Corporations and US Foreign Policy, Report to the Committee on Foreign Relations, United States Senate. Jan. 1975. 
PAINTER, D. S. Public power and private policy: multinational oil corporations and US Foreign Policy, 1941-1954. Johns Hopkins University Press, 1986.

PAINTER, D. S. Oil and the Marshall Plan. The Business History Review, v. 58, n. 3, p. 359-383, Autumn 1984.

PETROLEUM Study. Hearings before a Subcommittee on Interstate and Foreign Commerce, United States House of Representatives, $81^{\text {st }}$ Congress, $2^{\text {nd }}$ session. 1950 .

QUANDT, W. Saudi Arabia in the 1980s: foreign policy, security, and oil. Washington, D.C.: Brookings Institution Press, 1981.

RECORDS of the Agency for International Development. Mutual Security Agency (Economic Cooperation Administration), Herbert Hoover Presidential Library, Oct. 1948.

REPORT on the Third World Petroleum Congress. United States Senate, $82^{\text {nd }}$ Congress, $2^{\text {nd }}$ Session. 1951.

RICHMAN, S. Ancient history: US conduct in the Middle East since World War II and the folly of intervention. Cato Institute Policy Analysis, Aug. 1991.

SCHWARZ, B. Why America thinks it has to run the world. The Atlantic Monthly, Jun. 1996.

THE ECONOMIST. Egypt's sterling balances. Jan. 1, 1949.

THE ECONOMIST. Selling for dollars. Jan. 1, 1949.

THE ECONOMIST. Marshall Plan for the creditors? Jan. 8, 1949.

THE ECONOMIST. Majors and minors in oil. Mar. 5, 1949.

THE ECONOMIST. Oil supplies - and demand. Oct. 8, 1949.

THE ECONOMIST. Oil trade in dollars and sterling. Dec. 3, 1949.

TUCKER, R. The purposes of American Power. Foreign Affairs, v. 59, n. 241, p. $248-271,1980-81$. 